Prof. Vesna MILANOVIĆ, $\mathrm{PhD}^{*}$

Graduate School of International Economics, Megatrend University, Belgrade

UDK $-339.138: 351.74$

Original scientific paper

Received: 22.06.2014.

\title{
The Relevance of Marketing Logic and Marketing Philosophy in The Police as a Citizens' Service
}

\begin{abstract}
This paper deals with the relevance of marketing logic and marketing philosophy in the police as a citizens' service. The research was conducted by analysis of domestic and foreign literature relevant to the topic of the paper - largely that in scientific journals (articles) in the field of social sciences, which are in the Serbian Citation index base and the Serbian Library Consortium for Coordinated Acquisition (Kobson) and articles publicshed on the Internet as well. It has been found that the police as a citizens' service implement the key postulates of marketing philosophy, while the satisfaction of citizens with the service provided by police in cooperation with citizens and other organizations in strategic partnership represents the most important one. However, measuring the efficiency of police performance by the parameters based on marketing philosophy is not that common in practice.

Up to the $20^{\text {th }}$ century, the focus of the research was the analysis of factors which affect behaviour of police officers and application of traditional indicators of the efficiency of their performance. Thus, future research should be concerned with the research of the needs, attitudes and behaviour of citizens in order to create adequate strategies of their satisfaction, while the satisfaction of police officers should be of consequential character. The aim of the paper was to encourage domestic and foreign professionals to get involved in the research of performances which determine the quality of relations between police and citizens, the factors which affect behaviour of citizens, their satisfaction and encourage police officers to adhere to the principles of marketing philosophy in their work with citizens.
\end{abstract}

Key words: marketing, police as citizens' service, citizen satisfaction.

\footnotetext{
${ }^{*}$ Full professor, scientific field of marketing. E-mail: vmilanovic@megatrend.edu.rs

"* The work presented here was supported by the Serbian Ministry of Education and Science (project III 45003, project III 44006).
} 


\section{Introduction}

According to a traditional concept, the police are a bureaucratized and hierarchically structured organization (Bordus, Reiss, 1967) which primarily reacts to incidents in a society, whereas its preventive function is of secondary significance. Although the traditional indicators (e.g. response time, arrest percentage, resolved case percentage) are important for the assessment of policing efficiency, it is vital to evaluate their work from the point of view of responding to expressed needs of the citizens in the course of their interaction (Fyfe, 1993). When the police are observed as an organization that meets the needs of citizens - as a service, the quality of their services, such as estimated by the citizens, is the indicator of successfulness of their work (Watson, 1994 in Dietz, 1997:87), and satisfaction of citizens with the work and relations of the police with them ${ }^{1}$ shows their symbiosis within a community (Божовић, 2012; Никач, 2010). The essence of marketing philosophy consists of satisfaction of citizens (adapted from McGee, Spiro, 1988).

Given the fact that the police are an institution within the public sector, there can be no complete implementation of the marketing conception, as it implies that an organization survives to the extent to which it manages to satisfy the needs of the users and make profit (Милисављевић, 2006:9). Bearing this in mind, the paper discusses marketing philosophy ${ }^{2}$ rather than the marketing conception. Modern police are a civil service just like any other organization is the customer service, notwithstanding its profit orientation - bearing in mind the interests of the target group (Никач, 2013; Николић, 2012). Transparency of police as the civil service is evident in the concept of community policing ${ }^{3}$.

\footnotetext{
${ }^{1}$ Ambivalent expectations from the police on the part of citizens on the one hand and the fact that the service provided by the police does not comprise only one or several homogenous services, but rather a heterogeneous set of services, on the other, make it more difficult to measure citizen satisfaction which in itself is a result of a personal experience and perception of each individual. It is therefore hard to generalise, so that there are numerous parameters of citizen satisfaction. A study found out that the degree fo security that the citizens feel is of the greatest importance for their shaping of opinion on police work, and the conduct of police officers in direct encounters came second: Ashcroft, J., Daniels, D., Hart, S., (2002). Satisfaction With Police - What Matters? US Department of Justice Office of Justice Programs National Institute of Justice, USA.

2 Marketing philosophy is essentially based on the needs of those for whose sake an organisation exists - the citizens and the society as a whole, as the users of the public sector services - in this case the police.

${ }^{3}$ Community policing is a new concept of police organisation; it is a philosophy that promotes organisational strategies which support systematic partnership within a community, strategies for improving the police-citizen relations and strengthening the police efficiency in crime prevention and control. Vitality of community policing depends on social structures and is
} 
The objective of the paper is to present the relevance of the marketing logic and the fundamental premises of marketing philosophy within the police as the civil service. It is at the same time the hypothesis of the research. The paper comprises a number of sections, besides the compulsory elements, including: Methodology and justification of the research; Results (1) Relevance of the marketing logic in the research of public relations between police and the general public performed so far; Discussion of the results (1); Results (2): The implementation of basic postulates of marketing philosophy in policing; Discussion of the results (2).

\section{Methodology and justification of the research}

The study which is subject of this paper has been based on an analysis of Serbian and foreign literature which is relevant for the topic in question - mostly scientific journals (papers) in the field of social sciences which are in the basis of the Serbian Citation Index (SCindex) and the basis of the Consortium of Serbian Libraries for Coordinated Acquisition (Kobson), as well as the papers published on the Internet. Browsing through the basis of SCindex for the word police in the title, abstract and/or keywords resulted in 298 articles, only three of which were from the area of economics. Including additional terms in the query yielded the following results: 12 papers for community policing (in Serbian), two papers mentioning community policing (in English), one paper for the query relation between the police and the citizens ${ }^{4}$. The basis did not include papers containing the following terms and expressions: interaction between police and citizens, citizen satisfaction with police work, citizen satisfaction, police image, marketing and police, police as a public service, needs of citizens and police, police behavior in relations with citizens. ${ }^{5}$

Theoretical and empirical analyses of the quality of performance in relations between the police and citizens and satisfaction of citizens were almost entirely absent from the national scientific papers.

\footnotetext{
greatest in communities with more wealthy and educated citizens and a dominant middle class: Skolnick, J. H., Bayley, D. H., (1988). Community Policing: Issues and Practices Around the World, US Department of Justice, National Institute of Justice, USA.

${ }^{4}$ The Internet:

http://scindeks.ceon.rs/SearchResults.aspx?query=ARTAK $\% 26$ and $\% 26$ policija\&page=0\&sort $=1 \&$ stype $=0$,

Accessed on 8th March, 2014.

${ }^{5}$ Ibid.
} 
Browsing the Kobson basis resulted in a significant number of papers in which findings of research into the relations between police and citizens were included (Table 1). ${ }^{6}$

Table 1 - The list of selected papers/studies in the field of research on relations between he police and citizens published in foreign journals (Kobson, the Internet)

\begin{tabular}{|c|c|c|}
\hline $\begin{array}{l}\text { Author/ } \\
\text { authors }\end{array}$ & Title of the study/paper & Journal/Publisher \\
\hline Westley & Violence and the Police & $\begin{array}{l}\text { American Journal of Sociology, } \\
\text { Vol. 59, No. 1, 1953:34-41. }\end{array}$ \\
\hline $\begin{array}{l}\text { Sykes, } \\
\text { Clark }\end{array}$ & $\begin{array}{l}\text { A Theory of Deference Exchange in } \\
\text { Police-Civilian Encounters }\end{array}$ & $\begin{array}{l}\text { American Journal of Sociology, } \\
\text { Vol. 81, No. 3, 1975:584-600. }\end{array}$ \\
\hline Sherman & $\begin{array}{l}\text { Causes of police behavior: The current } \\
\text { state of quantitative research }\end{array}$ & $\begin{array}{l}\text { Journal of Research in Crime } \\
\text { and Delinquency, Vol. 17, No. 1, } \\
\text { 1980:69-100, doi: } \\
\text { 10.1177/002242788001700106 }\end{array}$ \\
\hline $\begin{array}{l}\text { Spelman, } \\
\text { Brown }\end{array}$ & $\begin{array}{l}\text { Response time. Calling the police: } A \\
\text { replication of the citizen reporting } \\
\text { component of the Kansas City Response } \\
\text { Time Analysis }\end{array}$ & $\begin{array}{l}\text { DC: Police Executive Research } \\
\text { Forum, Washington, } 1981 .\end{array}$ \\
\hline $\begin{array}{l}\text { Smith, } \\
\text { Visher }\end{array}$ & $\begin{array}{l}\text { Street-level justice: Situational } \\
\text { determinants of police arrest decisions }\end{array}$ & $\begin{array}{l}\text { Social Problems, Vol. 29, No. 2, } \\
\text { 1981:167-177, doi: } \\
\text { 10.2307/800422 }\end{array}$ \\
\hline $\begin{array}{l}\text { Southgat, } \\
\text { Eklbom }\end{array}$ & Police-Public Encounters & $\begin{array}{l}\text { HM Stationery Office, 1986, } \\
\text { ISBN 0-11-340834-X }\end{array}$ \\
\hline Riksheim & Causes of police behavior revisited & $\begin{array}{l}\text { Journal of Criminal Justice, Vol. } \\
\text { 21, No. 4, 1993:353-382. } \\
\text { http://dx.doi.org/10.1016/0047- } \\
\text { 2352(93)90019-J }\end{array}$ \\
\hline $\begin{array}{l}\text { Kanduce } \\
\text { Greenleaf }\end{array}$ & $\begin{array}{l}\text { Police-citizen encounters: Turk on } \\
\text { norm resistance }\end{array}$ & $\begin{array}{l}\text { Justice Quarterly, Vol. 11, No. 4, } \\
\text { 1994:605-623, doi: } \\
\text { 10.1080/07418829400092451 }\end{array}$ \\
\hline Lundman & $\begin{array}{l}\text { Demeanor or crime? The Midwest City } \\
\text { police-citizen encounters study }\end{array}$ & $\begin{array}{l}\text { Criminology, Vol. 32, No. 4, } \\
\text { 1994:631-656, doi: } \\
\text { 10.1111/j.1745- } \\
\text { 9125.1994.tb01168.x }\end{array}$ \\
\hline $\begin{array}{l}\text { Mastrofs, } \\
\text { Snipes, } \\
\text { Parks, } \\
\text { Maxwell }\end{array}$ & $\begin{array}{l}\text { The helping hand of the law: Police } \\
\text { control of citizens on request }\end{array}$ & $\begin{array}{l}\text { Criminology, Vol. 38, No. } 2 \text {, } \\
\text { 2000:307-342, doi: } \\
\text { 10.1111/j.1745- } \\
\text { 9125.2000.tb00892.x }\end{array}$ \\
\hline $\begin{array}{l}\text { Weitzer, } \\
\text { Brunson }\end{array}$ & $\begin{array}{l}\text { Strategic Responses to the Police } \\
\text { among Inner-City Youth }\end{array}$ & $\begin{array}{l}\text { The Sociological Quarterly, Vol. } \\
50, \text { No. 2, 2009:235-256 }\end{array}$ \\
\hline
\end{tabular}

${ }^{6}$ The Internet: http://kobson.nb.rs/servisi.124.html, Accessed on 9th March, 2014. 
The Relevance of Marketing Logic and Marketing Philosophy in The Police as a Citizens' Service

\begin{tabular}{|c|c|c|}
\hline $\begin{array}{l}\text { Dai, } \\
\text { Frank, } \\
\text { Sun }\end{array}$ & $\begin{array}{l}\text { Procedural justice during police-citizen } \\
\text { encounters: The effects of process- } \\
\text { based policing on citizen compliance } \\
\text { and demeanor }\end{array}$ & $\begin{array}{l}\text { Journal of Criminal Justice, Vol. } \\
\text { 39, No. 2, 2011:159-168. }\end{array}$ \\
\hline $\begin{array}{l}\text { Rossler, } \\
\text { Terill }\end{array}$ & $\begin{array}{l}\text { Police Responsiveness to Service- } \\
\text { Related Requests }\end{array}$ & $\begin{array}{l}\text { Police Quarterly, Vol. 15, No. 1, } \\
\text { 2012:3-24, doi: } \\
\text { 10.1177/1098611111432679 }\end{array}$ \\
\hline $\begin{array}{l}\text { Jonathan- } \\
\text { Zamir, } \\
\text { Mastrofski } \\
\text { Moyal } \\
\end{array}$ & $\begin{array}{l}\text { Measuring Procedural Justice in } \\
\text { Police-Citizen Encounters }\end{array}$ & $\begin{array}{l}\text { The Sociological Quarterly, Vol. } \\
\text { 50, No. 2, 2013:235-256, doi: } \\
\text { 10.1080/07418825.2013.845677 }\end{array}$ \\
\hline $\begin{array}{l}\text { Mazeroll, } \\
\text { Antrobu, } \\
\text { Bennett, } \\
\text { Tyler }\end{array}$ & $\begin{array}{l}\text { Shaping Citizen Perceptions of Police } \\
\text { Legitimacy: A Randomized Field Trial } \\
\text { of Procedural Justice }\end{array}$ & $\begin{array}{l}\text { Criminology, Vol. 51, No. 1, } \\
\text { 2013:33-63, doi: 10.1111/j.1745- } \\
\text { 9125.2012.00289.x }\end{array}$ \\
\hline
\end{tabular}

Table 2 - The list of selected papers focusing on the factors which influence citizen satisfaction published in foreign journals (Kobson base and academic papers on the Internet)

\begin{tabular}{|c|c|c|}
\hline $\begin{array}{l}\text { Author/aut } \\
\text { hors }\end{array}$ & Title of the study/paper & Journal/Publisher \\
\hline $\begin{array}{l}\text { Tyler, } \\
\text { Folger }\end{array}$ & $\begin{array}{l}\text { Distributional and Procedural Aspects } \\
\text { of Satisfaction with Citizen-Police } \\
\text { Encounters }\end{array}$ & $\begin{array}{l}\text { Basic and Applied Social } \\
\text { Psychology, Vol. 1, No. 4, } \\
\text { 1980:281-292, } \\
\text { doi: } \\
\text { 10.1207/s15324834basp0104_1 }\end{array}$ \\
\hline $\begin{array}{l}\text { Reisig, } \\
\text { Chandek }\end{array}$ & $\begin{array}{l}\text { The effects of expectancy } \\
\text { disconfirmation on outcome } \\
\text { satisfaction in police-citizen encounters }\end{array}$ & $\begin{array}{l}\text { Policing: An International } \\
\text { Journal of Police Strategies \& } \\
\text { Management, Vol. 24, No. 1, } \\
\text { 2001:88-99, } \\
\text { doi: 10.1108/13639510110382278 }\end{array}$ \\
\hline $\begin{array}{l}\text { Alpert, } \\
\text { Dunham, } \\
\text { MacDonald }\end{array}$ & $\begin{array}{l}\text { Interactive Police-Citizen Encounters } \\
\text { that Result in Force }\end{array}$ & $\begin{array}{l}\text { Police Quarterly, Vol. 7, No. } \\
\text { 4, 2004:475-488, } \\
\text { doi: } 10.1177 / 1098611103260507\end{array}$ \\
\hline Skogan & $\begin{array}{l}\text { Citizen Satisfaction with Police } \\
\text { Encounters }\end{array}$ & $\begin{array}{l}\text { Police Quarterly, Vol. 8, No. } \\
\text { 3, 2005:298-321, } \\
\text { doi: 0.1177/1098611104271086 }\end{array}$ \\
\hline Murphy & $\begin{array}{l}\text { Public Satisfaction with Police: The } \\
\text { Importance of Procedural Justice and } \\
\text { Police Performance in Police-Citizen } \\
\text { Encounters }\end{array}$ & $\begin{array}{l}\text { Australian \& New Zealand } \\
\text { Journal of Criminology, Vol. } \\
\text { 42, No. 2, 2009:159-178, } \\
\text { doi: } 10.1375 / \text { acri.42.2.159 }\end{array}$ \\
\hline Hinds & $\begin{array}{l}\text { Public satisfaction with police: the } \\
\text { influence of general attitudes and } \\
\text { police-citizen encounters }\end{array}$ & $\begin{array}{l}\text { International Journal of Police } \\
\text { Science \& Management, Vol. } \\
\text { 11, No. 1, 2009:54-66. }\end{array}$ \\
\hline
\end{tabular}


The listed studies mainly presented traditional factors of measuring efficiency of policing and factors which influence the behavior of police officers during encounters with the citizens. ${ }^{7}$

The search of the Kobson base established that there were a modest number of papers which presented the findings of researching factors which influence the citizen satisfaction (Table 2 ). ${ }^{8}$

The listed papers analyzed the influence of situational factors on the police-citizen relation, as well as those that influence the behavior of the parties in an encounter, whereas the research of citizen satisfaction was more modest ${ }^{9}$. This paper therefore opens with a thoroughly performed analysis of the so far obtained research results that focus on the police-citizen relation in order to establish whether they are based on the marketing logic, followed by an analysis of the implementation of basic postulates of marketing philosophy in the work of police.

\section{Results (1): Relevance of the marketing logic in the research of the police-public relation}

A pioneering paper on the analysis of behavior of police officers, Westley (1953) stated that police officers tend to view violence as morally justifiable and legitimate if it serves the justice. Since the publication of this paper the research of police officers' conduct has drawn attention of scientific and expert public.

During 1970s it was believed that the conduct of police officers was mostly influenced by normative and interpersonal factors (Sykes, Clark, 1975). It was the decade during which an initial contribution was made to the analysis of a wider range of factors on the police-citizen relation, and in the 1980 s the topical issue on which research focused was that of time of citizens' calls and the police response time (Spelman, Brown, 1981). It was established that the duration of an "intervention" and arrest as a possible outcome were mostly influenced by situational factors (Smith, Visher, 1981),

\footnotetext{
${ }^{7}$ They analyzed the influence of normative, sociological and psychological factors, as well as the influence of fairness and other personal characteristics of police officers on the citizen satisfaction with encounters, regardless of their outcome, etc.

${ }^{8}$ Ibid.

9 The listed papers established that the degree of citizen satisfaction with the police was influenced by social and political systems, as well as the demographic, economic, social and cultural environment or the community profile, and thereby the citizen profile. There were differences in views of the citizens regarding the police and the relation of police officers, depending on the sex, age, educational levels, occupation - job position, level of urbanization of the area in which they live, ethnic, racial or religious background, social status, psychological profile, etc. The studies presented the findings of empirical research that suggested this differentiation.
} 
and among them the presence of observers (Riksheim, 1923). Tyler and Folger (1980) found that fairness of officers, regardless of the outcome, led to a greater satisfaction of the citizens. Sociologists were focused on studying the influence of social and cultural norms on the officers' behavior (Kanduce, Greenleaf, 1994). A study in which Mastrofski (1999) identified six characteristics of the police, relying on the findings of characteristics of service quality in the private sector ${ }^{10}$ suggested that the following characteristics were relevant for both the public and the private sector: alertness, reliability, responsiveness, competence, manners, and honesty. Hence the behavior of officers was influenced by the type of service, situational factors and personal characteristics, whereas arrest decision were mostly influenced by the legal grounds pertaining to public order violations (Mastrofski et al., 2000).

In the first decade of the $21^{\text {st }}$ century authors made a turn in research - they focused on the citizens' satisfaction. They found that the citizens' expectations in terms of the outcome influenced their satisfaction and that an increase in the gap between the expected and actual outcome was inversely proportional to satisfaction (Reisig, Chandek, 2001). It was also established that the police-public relations depend on how the citizens are treated by the police (Weitzer, Brunson, 2009), or how they mutually treat one another (Alpert et al., 2004; Skogan, 2005). Greater mutual respect contributes to more efficient carrying out of the procedure (Dai et al., 2011), but also to the impartiality of police officers' decisions (Mazerolle et al., 2013). The citizens' satisfaction is mostly influenced by the way in which a procedure is carried out, if a contact has been initiated by the officers, and the officers' performance if the contact has been initiated by the citizens (Murphy, 2009). Satisfaction of the citizens who initiate contacts predominantly influences satisfaction of the general public. Consequently, satisfaction of the general public shapes the citizens' attitudes towards the police (Hinds, 2009) ${ }^{11}$. According to the marketing logic, it is up to the police officers to steer the relations with citizens in such a way as to lead to mutual satisfaction with an emphasis on citizen satisfaction. Therefore Rossler and Terill believe that the officers' response to the citizens' demands (non-standard ones) are most frequently influenced by situational factors and personal characteristics (Rossler, Terill, 2012). Police officers are the last link in providing services

\footnotetext{
${ }^{10}$ Parasuraman, A., Zeithaml, V. A., Berry, L. L., (1988). Servqual: A multiple-item scale for measuring consumer perceptions of service quality, Journal of Retailing, Vol. 64, No. 1, pp. $12-40$.

${ }^{11}$ The role of the media should not be neglected as they represent a powerful mechanism for communication with the community. Media reports on police can have a significant bearing on the public perception of police and the formation of citizens' attitudes regarding police. For further reading: Кешетовић, Ж., (2000). Односи полищије са јавношћу, ВШУП, Београд.
} 
to the citizens and they can most influence citizen satisfaction. Important issues regarding the police-public relations are best addressed by direct observation of their interaction (Jonathan-Zamir et al., 2013). The degree of observance for the procedures in police work from the citizens' perspective has so far been analyzed mostly by research using a questionnaire or an interview (Jonathan-Zamir et al., 2013).

\section{Discussion of the results (1)}

Until the end of the $20^{\text {th }}$ century, the largest portion of research presented in papers was focused on the traditional indicators of efficiency of police work and the factors that influence the behavior of police officers in their encounters with citizens and in direct contact between them. Although very useful, such research is insufficient in contemporary conditions. Efficiency of policing is not a primary measure of their success. Since the beginning of the $21^{\text {st }}$ century, the research focus has gradually shifted towards citizen satisfaction, which is completely supported by the marketing logic. The police should strive to improve the quality of their relations with the citizens and citizen satisfaction. However, it is by no means easily achieved. Citizen satisfaction is not a new concept, but it is measured inconsistently. It is frequently the result of one item among many others in the questionnaire (Watson, 1994 in Dietz, 1997:87). Hence the need for empirical research of the attitudes and expectations of the citizens and satisfactory performance on the one hand and measuring the citizens' satisfaction on the other. The findings of more recent studies presented in the paper suggest the same.

\section{Findings (2): Implementation of basic postulates of marketing philosophy in policing}

Modern police is a proactively orientated organization and organizations of this orientation are more successful than those that react to changes in the surroundings (Kotler, Keller, 2006). Citizens are the primary partner of police and their involvement is a prerequisite for efficient and accountable police (Millen, Stephens, 2012). A concept of police defined in this way is based on marketing philosophy according to which "delivery of values" 12 is performed in cooperation with the citizens and other partners, striving for a

\footnotetext{
${ }^{12}$ According to this concept, the citizens do not receive a service, but the value which the service brings along and which is created in keeping with the citizens' expectations.
} 
strategic partnership along the chain of values. ${ }^{13}$ The government policy to demand effective and efficient policing faces the police with a challenge they must view the citizens as the users of their services (Guyot, 1991; Mawby, Worthington, 2002:871). On the other hand, the burden is entirely on the police, because they represent the most specific organization within the public sector which is expected to show efficient communication and accountability. The public is most frequently dissatisfied with police work which correlates with fear of crime and contributes to the already insatiable demand for police services. External pressures make the police engage in marketing as a means to send messages for keeping the trust of all interested parties. In this sense, the police have to compete with other organizations of the public sector struggling for limited resources (Mawby, Worthington, 2002:871) although the social causes of crime could be neutralized only in their close mutual cooperation ${ }^{14}$. The task of police in the area of crime and their task in the area of the so-called social and service work are not two separate tasks but "two interdependent areas of police work" but also "the tasks that cannot always be easily distinguished" (Милосављевић, $1997: 164 / 165)$. If the police are to be successful it is necessary that the citizens trust them and are satisfied with police work. However, it is not easy to win and keep the public trust in a situation when the police are unable to completely contain and prevent crime. Research has shown that voluntary cooperation between the citizens and the police weakens if the citizens doubt the legitimacy of the police (Jackson et al., 2012).

The concept of community policing, according to the research of Smith et al. (2001), allows police officers to spend more time on citizen relations, which is the aim of every organization expressed as an increase in the value of its relations with the users of its services (Kotler, Keller, 2006:151). The essence is that the police officers understand that their task is to make the citizens satisfied with the services they provide, and not primarily the process of providing the service in itself (adapted from Levitt, 1960). Hence it is more important what the citizens think of the police than what the police think about the quality of their performance. When forming the attitude regarding the police, it should be noted that the citizens do not bear in mind the statistics on crime rates, they bear in mind the conduct of the police officers in personal contacts with them and ability for prompt response (Mastrofski, 1999). Thus the police officers who establish personal contacts

\footnotetext{
${ }^{13}$ The chain of values is a means of identifying the road towards creating more value for the citizens. In this chain every ring (organization) focuses on key activities in the area of its competence so that the value for the citizens should be maximized. According to: Porter, M., (1985). Competitive Advantage: Creating and Sustaining Superior Performance, The Free Press, New York.

${ }^{14}$ With a network of social services and institutions.
} 
with the citizens are primarily responsible for respectability of the police. This is supported by the experience of the police in the United Kingdom (Emsley, 2010:10, 299 in Emsley, 2012:43). ${ }^{15}$

Depoliticization of the police is the first prerequisite for creating the police that would enjoy respect as a true public service of all citizens. Emsley states that it is not easy to improve respectability (change the image), because brand marketing is one thing and the behavior in the field ${ }^{16}$, in order to be efficient, generally has to be pragmatic and relevant to the society and the circumstances for which it is intended (Emsley, 2012:53). In order to eradicate conservative views of the police and overcome prejudice, the police should focus on the citizens' needs - they will have to adopt management and marketing techniques (Mawby, Worthington, 2002:871). To achieve this, they first need to influence a change in the opinion of the insiders regarding the value of marketing, i.e. to apply "the marketing of marketing orientation". The marketing of the marketing orientation is a step in the process of transforming the police in a citizens' service (Mawby, Worthington, 2002:872).

\section{Results discussion (2)}

The police bear the burden as a public sector institution with a specific role in the society and the system. They are not the citizens' service in the countries/societies where they are politicized and in which they have not been reformed - there they are still traditionally orientated. The police have to go a long way of reform and change of their respectability (repositioning). There many obstacles, such as prejudices about the police as a citizens' service and they are present equally in the society and among the police themselves. Citizen satisfaction as a measure of successful policing is still not seen as a primary goal, so the empirical research of citizens' satisfaction is modest ${ }^{17}$. Therefore the discussion presented in the paper may be seen as the personal view of the author.

In order to promote public relations, the police should be familiar with the opinion of citizens regarding police, which falls within the

\footnotetext{
${ }^{15}$ The International Police Assistance Board (IBAP) was established in 2008 by the minister of the interior in order to coordinate police missions abroad and develop a strategic overview of the British objectives in the international police assistance. The opening sentence of the current leaflet of the Board reads as follows: "The UK police are one of the most recognized and highly appreciated international brands." Until recently, British police officers were a joking matter because they are called bobbies (puppies). Even the press ridiculed the way in which senior officers adopted new approaches in work and communication.

${ }^{16}$ It refers to activities aimed at changing the reputation.

${ }^{17}$ Most studies focused on exploring police conduct towards citizens or studying the factors which determine the citizens' conduct upon encounters with the police.
} 
marketing domain of exploring the citizens' attitudes. The fact that the citizens' views are heterogeneous emphasises the significance of a strategy of differentiated marketing of police-citizen communication, as well as concentrated communication 'one on one'.

\section{Conclusion}

The research presented in this paper allows us to draw the following conclusions:

1) In the traditional concept, the police are unable to identify the needs of the citizens and the society, and the citizens are unable to understand the true role of the police in the society. The police cannot establish effective and efficient two-way communication, which leads to further separation from the needs of the society and the citizens. This concept is not based on the marketing logic and marketing philosophy.

2) Within the concept of community policing, which emphasises the role of police as a citizens' service, citizen satisfaction is viewed as a premise of the police existence. Introducing a philosophy according to which the police should be a citizens' service implies the development of both integrated and internal marketing and an improvement of relation (external) marketing within the police organisation.

3) Integrated marketing implies integrating police services, the mode of their delivery, the marketing of communication and environment in which services are provided which constitutes the so-called transactional marketing or tactical instruments of marketing.

4) Strengthening the internal marketing - recruitment of all employees on all organisational levels for the marketing service, i.e. the citizens' service, would fasten the acceptance of citizen satisfaction as a measure of successful policing.

5) Marketing philosophy in the police brings about citizen satisfaction. Measuring satisfaction is a complex process which calls for exact parameters, methods and techniques, experts and citizens willing to openly express their views. Although the listed restrictions may discourage researchers, it is vital to intensify research of the parameters of citizen satisfaction, empirical measuring of citizen satisfaction and satisfaction enhancement strategies. The suggested research would contribute to further promotion of marketing philosophy in the police. 


\section{References}

1. Alpert, P. G., Dunham, G. R., MacDonald, M. J., (2004). Interactive Police-Citizen Encounters that Result in Force, Police Quarterly, Vol. 7, No. 4, pp. 475-488, doi: 10.1177/1098611103260507.

2. Bordua, D. J., Reiss, J. A., (1967). Law enforcement, in The uses of sociology, edited by Lazarsfeld, F. P., Sewell, H. W., Wilensky, L. H., Basic Books, New York.

3. Божовић, М., (2012). Међународни стандарди полицијског поступаға и примене полищијских овлашћењ а у Републици Србији, Безбедност, год. 54, број 3, Београд, стр. 335-350.

4. Dai, M., Frank, J., Sun, I., (2011). Procedural justice during policecitizen encounters: The effects of process-based policing on citizen compliance and demeanor, Journal of Criminal Justice, Vol. 39, No. 2, pp. 159-168.

5. Dietz, A. C., (1997). Evaluating community policing: quality police service and fear of crime, Policing: An International Journal of Police Strategies \& Management, Vol. 20, No. 1, pp. 83-100.

6. Emsley, C., (2012). Marketing the Brand: Exporting British Police Models 1829-1950, Policing, Vol. 6, No. 1, pp. 43-54, doi: 10.1093/police/par061.

7. Fyfe, J., (1993). Good policing, The socio-economics of crime and justice, edited by Fors, B., pp. 269-290, M. E. Sharpe, Armonk, New York.

8. Guyot, D., (1991). Policing as though people matter, Temple University Press, Philadelphia.

9. Hinds, L., (2009). Public satisfaction with police: the influence of general attitudes and police-citizen encounters, International Journal of Police Science \& Management, Vol. 11, No. 1, pp. 54-66.

10. Jackson, J., Bradford, B., Hough, M., Myhill, A., Quinton, P., Tyler, T. R., (2012). Why do people comply with the law? Legitimacy and the influence of legal institutions, British Journal of Criminology, Vol. 52, No. 6, pp. 1051-1071.

11. Jonathan-Zamir, T., Mastrofski, D. S., Moyal, S., (2013). Measuring Procedural Justice in Police-Citizen Encounters, The Sociological Quarterly, Vol. 50, No. 2, pp. 235-256, doi: 10.1080/074 18825.2013.845677.

12. Kanduce, L. L., Greenleaf, G. R., (1994). Police-citizen encounters: Turk on norm resistance, Justice Quarterly, Vol. 11, No. 4, pp. 605623, doi: 10.1080/07418829400092451.

13. Kotler, P., Keller, K., (2006). Marketing Management, Upper Sadle River, New Jersey. 
14. Levitt, T., (1960). Marketing Myopia, Harvard Business Rewiev, Vol. 38, No. July/August, pp. 57-66.

15. Mastrofski, S. D., (1999). Policing for people. Ideas in American Policing, Police foundation, интернет:

http://www.policefoundation.org/sites/g/files/g798246/f/Mastrofski\%2 0\%281999\%29\%20-\%20Policing\%20For\%20People.pdf; доступан 3. 3. 2014.

16. Mastrofski, S. D., Snipes, J. B., Parks, R. B., Maxwell, C. D., (2000). The helping hand of the law: Police control of citizens on request, Criminology, Vol. 38, No. 2, pp. 307-342, doi: 10.1111/j.17459125.2000.tb00892.x.

17. Mawby, C. R., Worthington, S., (2002). Marketing the Police - from a Force to a Service, Journal of Marketing Management, Vol. 18, No. 910, pp. 857-876, doi: 10.1362/0267257012930411.

18. Mazerolle, L., Antrobus, E., Bennett, S., Tyler, R. T., (2013). Shaping Citizen Perceptions of Police Legitimacy: A Randomized Field Trial of Procedural Justice, Criminology, Vol. 51, No. 1, pp. 33-63, doi: 10.1111/j.1745-9125.2012.00289.x.

19. McGee, L. W., Spiro, R. L., (1988). The Marketing Concept in Perspective, Business Horizons, Vol. 31, No. 3, pp. 40-45.

20. Millen, F., Stephens, M., (2012). Police Authorities, Accountability, and Citizenship, Policing, Vol. 6, No. 3, pp. 261-271, doi: 10.1093/police/pas022.

21. Милисављевић, М., (2006). Стратегијски маркетинг, Економски факултет, Београд.

22. Милосављевић, Б., (1997). Наука о поличији, Полицијска академија, Београд.

23. Murphy, K., (2009). Public Satisfaction With Police: The Importance of Procedural Justice and Police Performance in Police-Citizen Encounters, Australian \& New Zealand Journal of Criminology, Vol. 42, No. 2, pp. 159-178, doi: 10.1375/acri.42.2.159.

24. Никач, Ж., (2010). Новеле у кривичноправној области од значаја за поступање припадника полищије, Безбедност, год. 52, бр. 3, Београд, стр. 108-123.

25. Никач, Ж., (2013). Измене и допуне Закона о полицији Републике Србије - критички осврт на важније новеле, Безбедност, год. 55, Београд, стр. 180-196.

26. Николић, В., (2012). Радноправни положај полицијских службеника, Безбедност, год. 54, број 3, Београд, стр. 350-365.

27. Reisig, M. D., Chandek, M. S., (2001), The effects of expectancy disconfirmation on outcome satisfaction in police-citizen encounters, 
Policing: An International Journal of Police Strategies \& Management, Vol. 24, No. 1, pp. 88-99, doi: 10.1108/13639510110382278.

28. Riksheim, E. C., (1993). Causes of police behavior revisited, Journal of Criminal Justice, Vol. 21, No. 4, pp. 353-382.

29. Rossler, T. M., Terill, W., (2012). Police Responsiveness to ServiceRelated Requests, Police Quarterly, Vol. 15, No. 1, pp. 3-24, doi: 10.1177/1098611111432679.

30. Skogan, W., (2005). Citizen Satisfaction with Police Encounters, Police Quarterly, Vol. 8, No. 3, pp. 298-321, doi: $0.1177 / 1098611104271086$.

31. Smith, B. W., Kenneth, J. N., Frank, J., (2001). Community Policing and the Work Routines of Street-Level Officers, Criminal Justice Review, Vol. 26, No. 1, pp. 17-37, doi: 10.1177/073401680102600103.

32. Smith, D. A., Visher, C. A., (1981). Street-level justice: Situational determinants of police arrest decisions, Social Problems, Vol. 29, No. 2, pp. 167-177, doi: 10.2307/800422.

33. Spelman, W. G., Brown, D. K., (1981). Response time. Calling the police: A replication of the citizen reporting component of the Kansas City Response Time Analysis, DC: Police Executive Research Forum, Washington.

34. Sykes, R. E., Clark, J. P., (1975). A Theory of Deference Exchange in Police-Civilian Encounters, American Journal of Sociology, Vol. 81, No. 3, pp. 584-600.

35. Tyler, R. T., Folger, R., (1980). Distributional and Procedural Aspects of Satisfaction With Citizen-Police Encounters, Basic and Applied Social Psychology, Vol. 1, No. 4, pp. 281-292, doi:10.1207/s15324834basp0104_1.

36. Weitzer, R., Brunson, R. K., (2009). Strategic Responses to the Police among Inner-City Youth, The Sociological Quarterly, Vol. 50, No. 2, pp. 235-256, doi: 10.1111/j.1533-8525.2009.01139.x.

37. Westley, W. A., (1953). Violence and the Police, American Journal of Sociology, Vol. 59, No. 1, pp. 34-41. 


\section{Релевантност логике маркетинга и маркетинг филозофије у полицији као сервису грађана}

Апстракт: У раду је представљена релевантност логике маркетинга и маркетинг филозофије у полищији као сервису грађана. Истраживање је обављено кроз анализу домаће и стране литературе, релевантне за тему рада - углавном научних часописа (чланака) у области друштвених наука, који се налазе у бази Српског цитатног индекса, бази Конзориијума библиотека Србије за обједињену набавку, као и чланака публикованих на интернету. Утврђено је да полииија као сервис грађана почива на кључним постулатима маркетинг филозофије, од којих је најважнији сатисфакиија грађана услугом, коју полищија пружа у сарадњи са грађанима и другим организачијама кроз стратешко партнерство дуж иелог ланиа вредности. Међутим, у пракси је мање заступљено мерење ефикасности рада полиције показатељима који су засновани на перформансама маркетинг филозофије.

До краја 20. века углавном је доминирало истраживање фактора који опредељују понашање полииијских службеника и примена традиционалних показатеља мерења ефикасности рада полиције. Отуда будућа истражсиваьа треба преусмерити ка истраживању ставова и очекивања грађана како би се креирале адекватне стратегије повећања њихове сатисфакиије, док је сатисфакиија полицијских службеника последичног карактера. Циљ рада је да подстакне домаћу научну и стручну јавност на истраживања перформанси које детерминишу квалитет односа полииија - грађани, фактора који опредељују понашане грађана, перформанси сатисфакиије грађана, као и да подстакне припаднике полииије на значајније уважсаваье маркетинг филозофије у раду и у односу са грађанима.

Кључне речи: маркетинг, поличија - сервис грађана, сатисфакиија грађана. 